\title{
Clinical Study on the effectiveness of Rajayu Herbal Wellness Brews (Cholesterol Fighter and Sugar Regulator)
}

\author{
W. J. Wickramarachchi. ${ }^{1}$, R. S. C. G Rajapaksha. ${ }^{1}$, K. K. I Eranga ${ }^{1}$, J. A Liyanage ${ }^{2}$, P. A. N. \\ Punyasiri $^{3}$, G. M. W. A Chandrarathne ${ }^{3}$
}

\begin{abstract}
The study was carried out to investigate the effectiveness of two wellness herbal brews, Rajayu cholesterol fighter and sugar regulator that were introduced to the market by Nature's Beauty Creations Ltd, Sri Lanka. The study was designed as randomized controlled clinical study and the body conditions were investigated using laboratory and clinical investigation methods. The resulted data for Rajayu cholesterol fighter revealed that average of HDL, average of LDL, average of total cholesterol, HDL ratio, total cholesterol are slight different at the initial stage and the final stage of the tests within the normal range. The data obtained for the Rajayu herbal sugar regulator also revealed that the average total blood sugar was slightly decreased within normal range. Liver and kidney functions were not significantly different between two stages for both wellness brews. Hence the cholesterol fighter and sugar regulator did not cause any side effect or adverse effect at the end of the investigation.
\end{abstract}

Keywords - Cholesterol fighter, Kidney function, Liver function, Sugar regulator

\section{INTRODUCTION}

$\mathrm{T}$ HE industry of herbal brew other than tea operating in the international market is very diverse, ranging from large international corporations to many small domestic scale businesses run by the farmers. Products cover a wide span, from exclusive flavored herbal brews and to a great variety of branded and simply labeled sachet packets for the mass market [1].

In practice, these products have rarely been associated with serious health hazards. However, this does not mean that they are always safe in use, especially with regards to possible long term effects. Together with the fact that the products may be used extensively over a large part of the human lifespan, this has created a need to ensure, as far as possible, their safety-inuse by controlling the ingredients content and the toxicity [2]. Even though it has not proven clinically, some herbal brew products are available in the market with clinical claims on their labels [3]. Hence it is of utmost important to address these products in terms to their efficacy. As one of the leading cosmetic industries in Sri Lanka, Nature's Beauty Creations Ltd has introduced the natural herbal brews to the market to

\footnotetext{
${ }^{1}$ Gampaha Wickramarachchi Ayurveda Institute, University of Kelaniya, Sri Lanka.

${ }^{2}$ Department of Chemistry, University of Kelaniya, Sri Lanka.

${ }^{3}$ Nature's Beauty Creations Ltd, Millewa, Horana, Sri Lanka
}

regulate the cholesterol and sugar levels of human body.

Rajayu Sugar Regulator is formulated with selected herbs namely, Aegle marmelos (flowers), Cinnamomum zeylanicum (bark), Hemidesmus indicus (whole plant), Cymbopogon citratus (leaves), Cassia auriculata (flowers), Salacia reticulata (bark), Coccinia grandis (leaves) and Passiflora foetida (leaves) that are beneficial for regulating blood glucose level. Regular intake will also help to improve liver functions, purify blood and reduce gastric complications. Rajayu Cholesterol Fighter is a perfect blend of herbs of Murraya koenigii (leaves), Zingiber officinale (rhizome), Garcinia gummi-gutta (fruit rind), Centella asiatica (leaves), Cuminum cyminum (seeds), Tinospora cordifolia (bark), Piper nigrum (fruit) and Moringa oleifera (leaves) that are known for controlling high cholesterol levels and promote healthy blood lipid levels. The regular consumption will also help to improve blood circulation and promote longevity. Both herbal brews contain $100 \%$ pure herbals with no added synthetic colours, flavors or preservatives.

The present study was carried out with an aim to develop a reliable and reproducible test for the effectiveness of the Rajayu Natural Wellness Brews (Rajayu Sugar Regulator, and Rajayu Cholesterol Fighter) on human by testing whether the products are safe for consumption for a long period and by evaluating the effectiveness in terms of regulating of sugar levels in blood and lowering of cholesterol levels in blood.

\section{MATERIALS AND METHODS}

\section{A. Study design and recruitment of volunteers}

The study was designed to carry out as randomized controlled study. Forty (40) number of volunteer (for each wellness brew) males and females (1:1) aged between 20 and 55 years were recruited. Each volunteer was given a screen number. Exclusion criteria included pregnant or nursing mothers, medication or past medical history which may affect on the result of the study and participation in another simultaneous study. Withdrawal criteria included there not follow the conditions of the study information sheet, suffer any illness or accident or develop any condition during the study which could affect the outcome of the study, no longer wish to participate in the study and sponsor is not willing to continue the study. The medical, toxicity, sugar control effect and allergies history of the all participants were specially questioned. The contact numbers and email addresses were taken from the successive volunteers. This study and the 
ethical clearance were approved by the management board of the Gampaha Wickaramarachchi Ayurveda Institute, University of Kelaniya, Sri Lanka.

\section{B. Dose level and dosage forms}

In these clinical tests, the approximate amount of test material, each Rajayu natural wellness brew, was administered twice a day for three months to each volunteer. One dry sachet packet $(1.5 \mathrm{~g}$ of $)$ in one cup $(175 \mathrm{ml})$ of boiling water was used and left for 3-5 minutes. The sachet was taken out before drink.

\section{Investigations}

The body conditions were investigated using laboratory and clinical investigation methods. Lipid profile (HDL, LDL, cholesterol, triglycerides), liver functions (SGOT, SGPT) and kidney functions (S. creatinine) were carried out for the Rajayu cholesterol fighter. Meanwhile, the effectiveness of the Rajayu sugar regulator was investigated by testing fasting blood sugar, liver functions (SGOT, SGPT) and kidney functions (S. creatinine). Above clinical features were evaluated two times per month.

\section{RESULTS AND DISCUSSION}

Rajayu cholesterol fighter has been clinically tested for Average of HDL, Average of LDL, Average of ratio (Total cholesterol: HDL), Total Cholesterol, Average of triglycerides, Average of serum glutamic oxaloacetic transaminase (SGOT), Average of serum glutamic pyruvic transaminase (SGPT) and Average of serum creatinine. The resulted data revealed that average of HDL, average of LDL, average of ratio and total cholesterol showed a slight different at the initial stage and the final stage of the tests within the normal range. Average of total cholesterol decreased from $(204 \pm 6.5) \mathrm{mg} / \mathrm{dl}$ to $(196.1 \pm 5)$ $\mathrm{mg} / \mathrm{dl}$. Values of HDL, LDL and total cholesterol: HDL ratio altered from $(44.3 \pm 1.8) \mathrm{mg} / \mathrm{dl},(135 \pm 6.1) \mathrm{mg} / \mathrm{dl}$ and $(4.8 \pm 0.2)$ to $(46.6 \pm 1.3) \mathrm{mg} / \mathrm{dl},(129.3 \pm 5) \mathrm{mg} / \mathrm{dl}$ and $(4.2 \pm 0.1)$ respectively. Initial value of triglycerides was $(116.3 \pm 8) \mathrm{mg} / \mathrm{dl}$ and finally it indicated $(109.3 \pm 5.7) \mathrm{mg} / \mathrm{dl}$ (Figures 1; A-E).

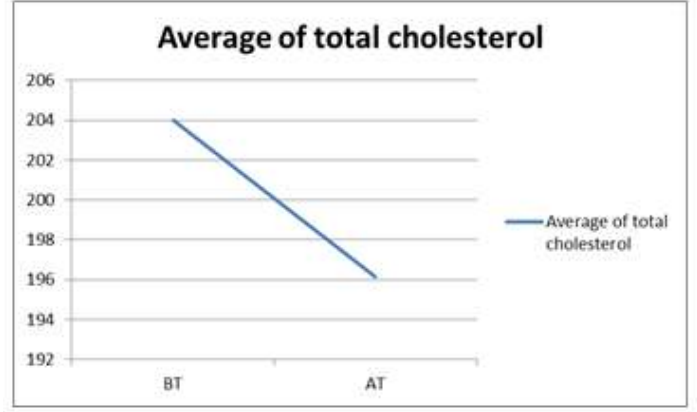

(A)

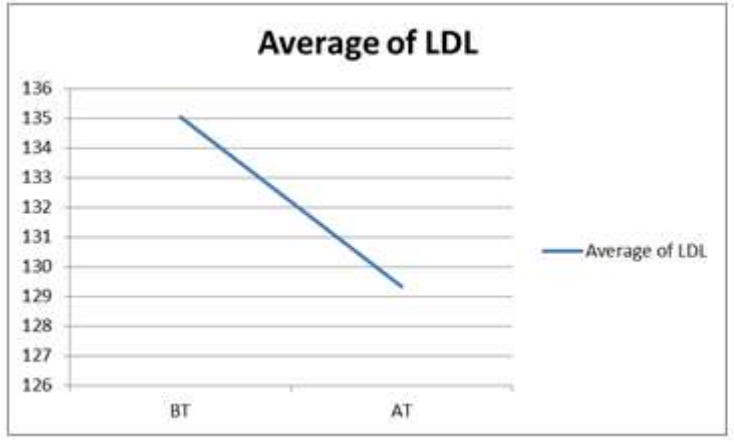

(C)

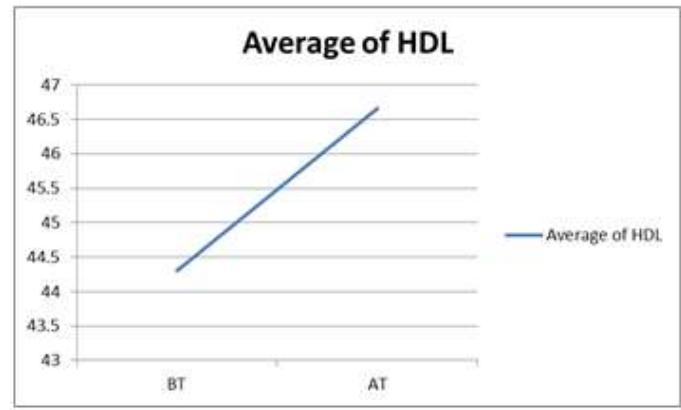

(B)

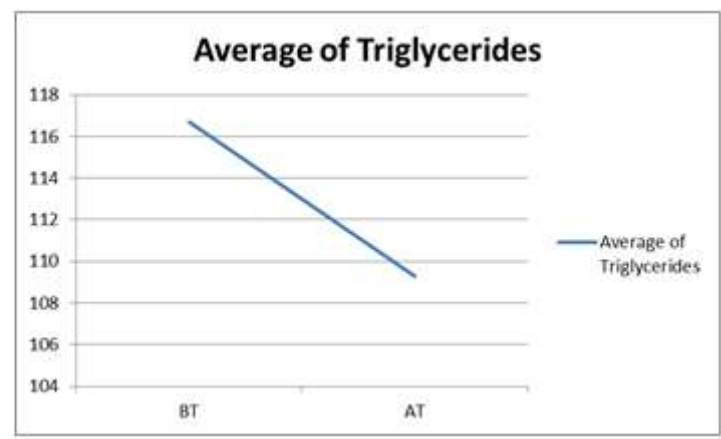

(D)

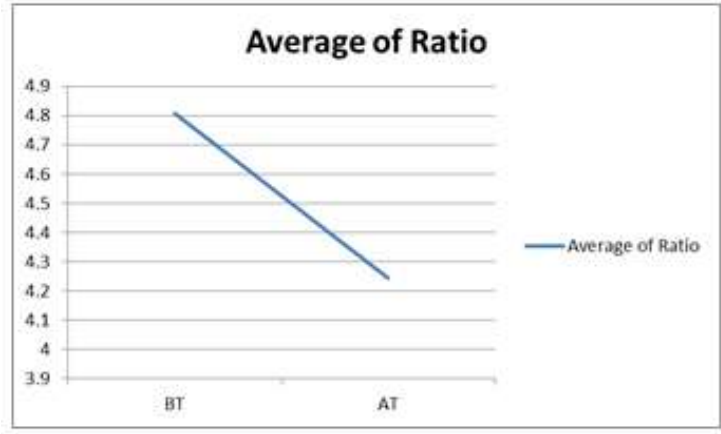

(E)

Fig 1: The average data of the total cholesterol (A). HDL (B). LDL (C). triglycerides (D). cholesterol:HDL ratio (E) tested for the Rajayu cholesterol fighter 
Liver functions and kidney functions were assessed using average of SGOT, average of SGPT and average of serum creatinine. Average of SGPT, SGOT and serum creatinine have slightly changed within the normal range from $(31.1 \pm 1.8),(32 \pm 1.2)$ units and $(0.82 \pm 0.03) \mathrm{mg} / \mathrm{dl}$ to $(32 \pm 1.6)$, $(31.9 \pm 1.1)$ units and $(0.77 \pm 0.05) \mathrm{mg} / \mathrm{dl}$ respectively. The results obtained for SGPT and SGOT and serum creatinine were not significantly different $(p>0.05)$ between initial and final stages.

Data obtained for the Rajayu herbal sugar regulator also revealed that the average total blood sugar was slightly decreased from $(117.5 \pm 7.7) \mathrm{mg} / \mathrm{dl}$ to $(110.3 \pm 5.4) \mathrm{mg} / \mathrm{dl}$ within normal range at the end of the investigation. Average data of SGPT, SGOT and S. creatinine showed minor differences from $(30.6 \pm 1.2),(32.1 \pm 1.8)$ units and $(0.8 \pm 0.02) \mathrm{mg} / \mathrm{dl}$ to (31.6 \pm 1.6$),(31.7 \pm 2)$ units and $(0.78 \pm 0.06) \mathrm{mg} / \mathrm{dl}$ respectively (Figure 2). The results of the tests for liver and kidney functions were not significantly different $(p>0.05)$ between initial and final stages of the investigation. Therefore, the results indicated the Rajayu sugar regulator also did not cause any adverse effect and it also proved the wellness brew has significant effectiveness to regulate the total blood sugar.

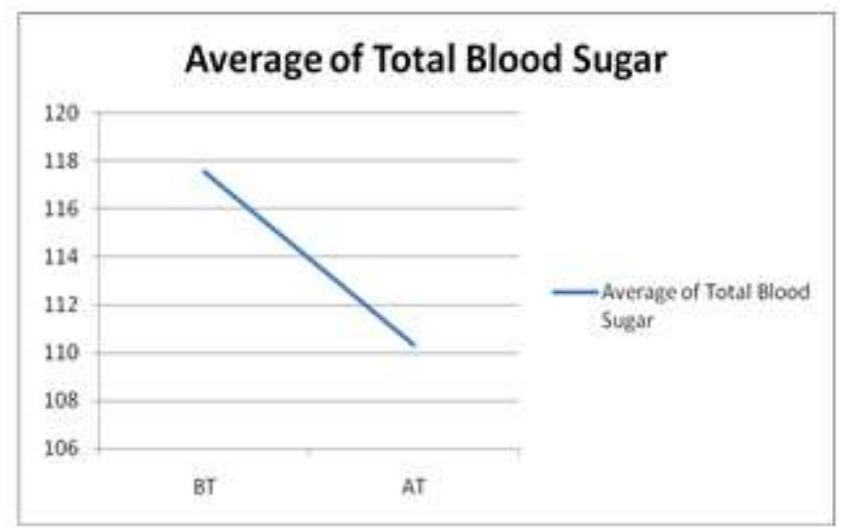

Fig 2: The data of average total blood sugar for the Rajayu sugar regulator

Herbal products may contain several active constituents or compounds that can act by several modes of action to influence multiple biological pathways and to alleviate the chronic symptoms, providing thereby multifaceted benefits [4]. Plenty of researches have been carried out in order to investigate the potential of lowering cholesterol and the regulation of blood glucose level of the plants which have used to prepare Rajayu wellness herbal brews without harmful effects to the human body [5],[6],[7],[8],[9]. The data obtained for liver and kidney function tests did not show a significant difference between initial stage and the final stage for both wellness brews (Table 1).
TAble 1: The Average Data Of The Initial Stage And The Final Stage OF THE Clinical TESTS For RAJAYu CHOLESTEROL Fighter AND RAJAYU SUGAR REGULATOR

\begin{tabular}{|c|c|c|c|}
\hline $\begin{array}{c}\text { Rajayu } \\
\text { wellness } \\
\text { brew type } \\
\end{array}$ & Test type & $\begin{array}{l}\text { Initial Stage } \\
\qquad(n=40)\end{array}$ & $\begin{array}{l}\text { Final Stage } \\
\qquad(n=40)\end{array}$ \\
\hline \multirow{8}{*}{$\begin{array}{l}\text { Cholesterol } \\
\text { Fighter }\end{array}$} & $\begin{array}{l}\text { Average of } \\
\text { Total } \\
\text { Cholesterol } \\
(\mathrm{mg} / \mathrm{dl})\end{array}$ & $(204 \pm 6.5)$ & $(196.1 \pm 5)$ \\
\hline & $\begin{array}{c}\text { Average of } \\
\text { Triglycerides } \\
\text { (mg/dl) }\end{array}$ & $(116.3 \pm 8)$ & $(109.3 \pm 5.7)$ \\
\hline & $\begin{array}{c}\text { Average of } \\
\text { HDL (mg/dl) }\end{array}$ & $(44.3 \pm 1.8)$ & $(46.6 \pm 1.3)$ \\
\hline & $\begin{array}{c}\text { Average of } \\
\text { LDL (mg/dl) }\end{array}$ & $(135 \pm 6.1)$ & $(129.3 \pm 5)$ \\
\hline & $\begin{array}{l}\text { Average of } \\
\text { ratio }\end{array}$ & $(4.8 \pm 0.2)$ & $(4.2 \pm 0.1)$ \\
\hline & $\begin{array}{l}\text { Average of } \\
\text { SGPT }\end{array}$ & $(31.1 \pm 1.8)$ & $(32 \pm 1.6)$ \\
\hline & $\begin{array}{c}\text { Average of } \\
\text { SGOT }\end{array}$ & $(32 \pm 1.2)$ & $(31.9 \pm 1.1)$ \\
\hline & $\begin{array}{c}\text { Average of S. } \\
\text { creatinine } \\
(\mathrm{mg} / \mathrm{dl})\end{array}$ & $(0.82 \pm 0.03)$ & $(0.77 \pm 0.05)$ \\
\hline \multirow{4}{*}{$\begin{array}{l}\text { Sugar } \\
\text { Regulator }\end{array}$} & $\begin{array}{c}\text { Average of } \\
\text { Total blood } \\
\text { sugar }(\mathrm{mg} / \mathrm{dl}) \\
\end{array}$ & $(117.5 \pm 7.7)$ & $(110.3 \pm 5.4)$ \\
\hline & $\begin{array}{c}\text { Average of } \\
\text { SGPT }\end{array}$ & $(30.6 \pm 1.2)$ & $(31.6 \pm 1.6)$ \\
\hline & $\begin{array}{c}\text { Average of } \\
\text { SGOT }\end{array}$ & $(32.1 \pm 1.8)$ & $(31.7 \pm 2)$ \\
\hline & $\begin{array}{l}\text { Average of S. } \\
\text { creatinine } \\
(\mathrm{mg} / \mathrm{dl})\end{array}$ & $(0.8 \pm 0.02)$ & $(0.78 \pm 0.06)$ \\
\hline
\end{tabular}

\section{CONCLUSION}

Rajayu cholesterol fighter has potential to control lipid profiles and Rajayu sugar regulator has significant effectiveness in regulating the total blood sugar. Both wellness brews did not cause any adverse or side effects.

\section{REFERENCES}

[1] Gardner E.J, Ruxton C.H, Leeds A.R. Black tea-helpful or harmful? A review of the evidence. Eur J Clin Nutr. (2007);61(1):3-18 https://doi.org/10.1038/sj.ejcn.1602489

[2] Tozer S., Safford B., Coroama M., Steiling W., Leneveu-Duchemin M.C., McNamara C., Gibney M. European consumer exposure to cosmetic products, a framework for conducting population exposure assessments. Food and Chemical Toxicology, (2007).45(11):2097- 108

[3] Gabriels G, Lambert M. Nutritional supplement products: does the label information influence purchasing decisions for the physically active? Nutr J (2013);12:133

https://doi.org/10.1186/1475-2891-12-133

[4] Kar A, Choudhary B.K, Bandyopadhyay N.G. Comparative evaluation of hypoglycaemic activity of some Indian medicinal plants in alloxan diabetic rats. J Ethnopharmacol. (2003);84:105-108 https://doi.org/10.1016/S0378-8741(02)00144-7

[5] Brenes, A.; Roura, E. Essential oils in poultry nutrition: Main effects and modes of action. Anim. Feed Sci. Technol. (2010), 158, 1-14. https://doi.org/10.1016/j.anifeedsci.2010.03.007 
[6] Broadhurst C.L, Polansky M.M, Anderson R.A. Insulin-like biological activity of culinary and medicinal plant aqueous extracts in vitro. J Agric Food Chem (2000) Mar;48(3):849-52.

[7] Joshi S.C, Jain P.K, A review on hypolipidaemic and antioxidant potential of some medicinal plants. World J Pharm Sci (2014);3(11):357-380

[8] Kamalakannan N, Stanley MPP (2003). Effect of Aegle marmelos Correa. (Bael) fruit on tissue antioxidants in streptozotocin diabetic rats. Indian J. Exp. Biol. 41:1285-1288.

[9] Smet E, Mensink R.P, Plat J., Effects of plant sterols and stanols on intestinal cholesterol metabolism: Suggested mechanisms from past to present. Molecular Nutrition and Food Research; (2012). 56: 10581072.

https://doi.org/10.1002/mnfr.201100722 